\title{
PARADIGMA HUMANIS PELAYANAN PUBLIK PADA KEBIJAKAN LARANGAN MUDIK 2021 DI PELABUHAN BAKAUHENI LAMPUNG
}

\section{THE PUBLIC SERVICE HUMANIST PARADIGM IN THE PROHIBITED POLICY OF 2021 AT BAKAUHENI PORT, LAMPUNG}

\begin{tabular}{|c|c|}
\hline $\begin{array}{l}\text { Adam Syahid } \\
\text { Universitas } \\
\text { Muhammadiyah Jakarta } \\
\text { email: } \\
\text { retnowatiwdtuti@yaho } \\
\text { o.com } \\
\text { Retnowati WD Tuti } \\
\text { Universitas } \\
\text { Muhammadiyah Jakarta } \\
\text { email: } \\
\text { retnowatiwdtuti@yaho } \\
\text { o.com }\end{array}$ & 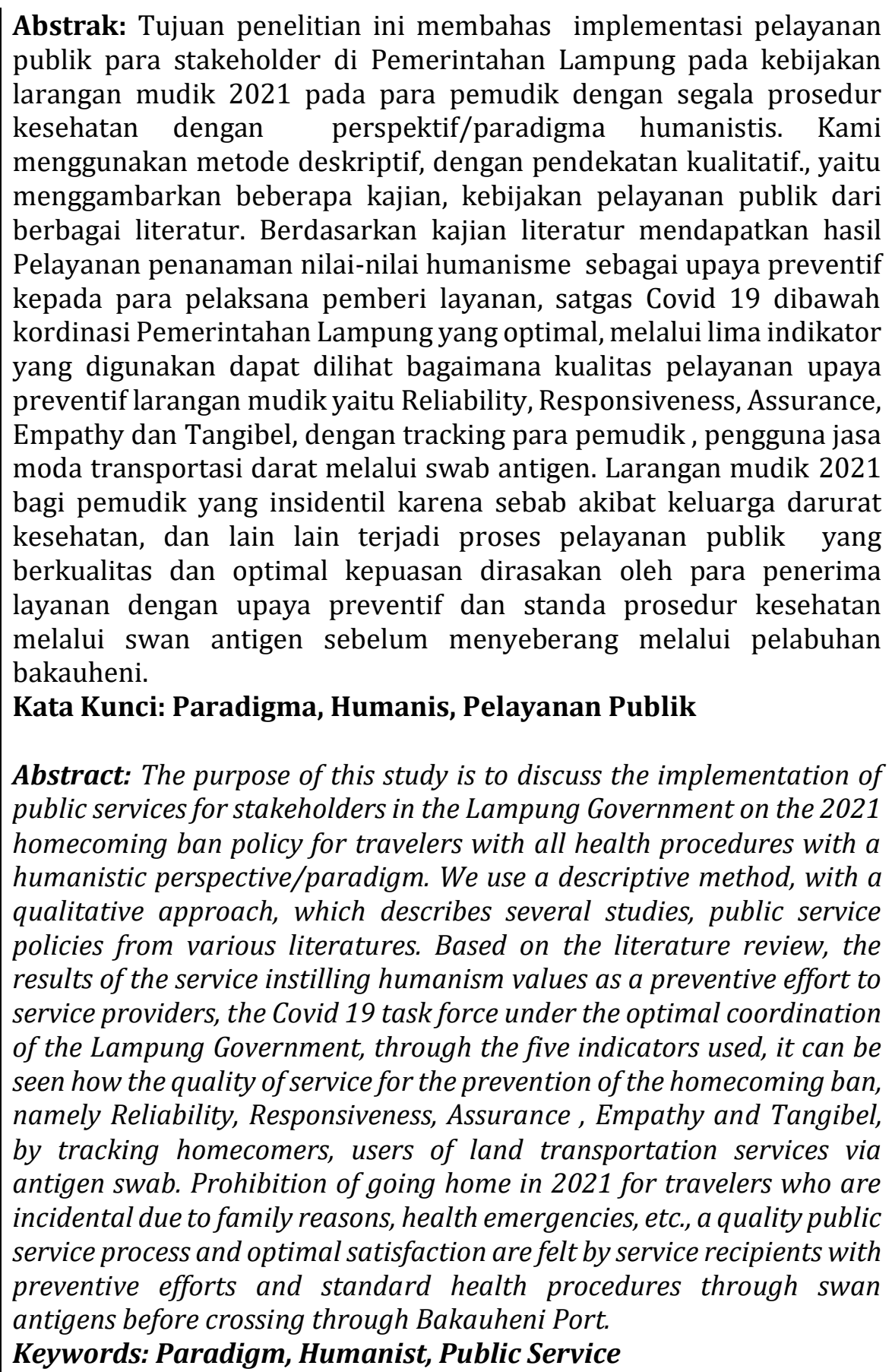 \\
\hline
\end{tabular}




\section{PENDAHULUAN}

Hari Raya Idul Fitri sudah menjadi tradisi bagi masyarakat Indonesia untuk melakukan tradisi ritual mudik. Ritualitas tradisi mudik yang membudaya merupakan fenomena sosial di Indonesia yang terjadi setiap tahun. Mudik pada dasarnya dimaknai warga pendatang dari desa yang telah bermigrasi cukup lama ke kota biasanya melakukan aktivitas mudik pulang ke kampung halaman, pada hari libur kerja yang panjang dan bermakna kultural seperti Lebaran Idul Fitri, bahkan Natal maupun Tahun Baru.

Dari tahun ke tahun, mudik tidak pernah menjadi hal yang mengkhawatirkan selain persoalan kemacetan, dan hal ini malah membuat masyarakat yang melakukan aktivitas mudik lebih berketahanan pada kendala macet selama di perjalanan menuju ke daerah tujuan masing masing pemudik.

Masyarakat Indonesia yang melakukan mudik pada tahun 2017 dan 2018 menembus angka lebih dari 20 juta orang. Sehingga dapat dikatakan sekitar $10 \%$ dari masyarakat indonesia terlibat dalam aktivitas tersebut. Selain berdampak sosial yang tinggi, aktivitas mudik berdampak pada pergerakan rantai perekonomian yang nilainya mencapai 9,7 Triliun Rupiah pada tahun 2019.

Pada tahun 2020 mudik menjadi hal yang sangat mengkhawatirkan karena adanya pandemi COVID-19 yang melanda Indonesia dan dunia. Dimulai awal 2 Maret 2020, kasus positif pertama diumumkan pada tren kasus COVID-19 di Indonesia semakin meningkat. Berdasarkan data yang dirilis Gugus Tugas Percepatan Penanganan COVID-19 per 8 Juni 2020, total jumlah kasus positif di Indonesia kini mencapai 32.033 kasus yang tersebar di hampir seluruh provinsi di Indonesia. Jumlah kasus terbanyak hingga saat ini berada di Provinsi DKI Jakarta dengan 8.033 kasus (25,8 persen) dan Provinsi Jawa Timur dengan 5.948 kasus $(19,1$ persen$)$.

Pada masa pandemi COVID-19, kota-kota besar tidak hanya menjadi simpul kegiatan ekonomi, tetapi juga menjadi simpul penyebaran COVID-19. Mobilitas manusia yang tinggi di wilayah perkotaan kini menjadi faktor utama dalam penyebaran COVID-19. Beberapa penelitian menunjukkan bahwa mobilitas manusia sangat berperan dalam penyebaran wabah (Hisi dkk., 2019; Merler \& Ajelli, 2012; Universitat Rovira i Virgili, 2018).

Data World Population Review mengatakan Indonesia terdiri dari 87,20\% Muslim, ini artinya pergerakan yang besar pada mudik tahunan. Mudik Jadi penyebab peningkatan tajam dalam jumlah kasus COVID-19 yang dikonfirmasi. Dalam konteks ini, fenomena 
mudik dipandang sangat mengkhawatirkan karena berpotensi menyebarkan COVID-19. Di Indonesia potensi penyebaran COVID-19 inilah yang menjadi pokok persoalan Ketika mobilitas masyarakat yang bergerak dari kota ke kampung halaman, membuat kerumunan yang dikhawatirkan membuat mata rantai klaster klaster baru penyebaran virus Covid 19. Lalu Pemerintah membuat kebijakan larangan mudik dengan regulasi Peraturan Menteri Perhubungan (Permenhub) Nomor 13 Tahun 2021 tentang Pengendalian Transportasi Pada Musim Idul Fitri 1442 H Dalam Rangka Pencegahan Penularan COVID-19.

Namun kebijakan pelarangan mudik 2021 ini menimbulkan implikasi dalam implementasinya dilapangan. Efektivitas kebijakan Larangan mudik 2021 ditinjau dari perspektif regulasi dan upaya adaptasi kehidupan New Normal dan Protokol Kesehatan dalam aktivitas mudik masyarakat, yang seharusnya Kebijakan Larangan Mudik ini di evaluasi seberapa besar eefektifitasnya dan menjadi problem solver. Seperti yang dilakukan Pemerintahan lampung berkolaborasi Bersama satgas Covid 19 dan Lembaga terkait membuat upaya preventif untuk para masyarakat yang melintasi atau menyeberang ke pulau jawa, atau sebaliknya menyeberang dari jawa ke sumatera.

\section{METODE}

Dalam artikel ini kami menggunakan pendekatan metode penelitian kualitatif. Dimana peneliti menjadi pusat penelitian yang menjadi alat utama dalam mencari data secara mendasar dan akurat. Pendekatan hubungan antar manusia dalam penelitian ini, selama proses penelitian, terkait orang orang yang terkait penelitian banyak berhubungan dengan peneliti.

Peneliti memandang pendekatan secara kualitatif akan membantu peneliti dalam mengumpulkan data. Hal ini ditinjau dari beberapa alasan. Pertama, karena peneliti meneliti mengenai sebuah kebijakan larangan mudik 2021 dalam efektivitas pengendalian mobilitas kendaraan umum, pribadi hingga manusianya dari kota ke desa, dan dari desa ke kota. maka peneliti merasa membutuhkan sejumlah data yang diperoleh dari lapangan yang bersifat nyata, terbaru, dan terpercaya. Data-data yang dibutuhkan peneliti adalah permasalah-permasalahan yang secara nyata terjadi di lapangan dan mencari solusi dalam memecahkan permasalahan tersebut. 


\section{HASIL DAN DISKUSI}

Keputusan Kebijakan larangan mudik 2021 Pada tanggal 16 Maret 2021, melalui beragam saluran media diungkapkan bahwa pada prinsipnya perjalanan mudik hari raya tahun 2021 tidak dilarang. Pernyataan Menteri Perhubungan RI Budi Karya Sumadi bahwa pada prinsipnya pemerintah tidak melarang mudik pada 2021. Kabar gembira ini direspon oleh masyarakat yang ingin melakukan mudik merayakan hari raya di kampung halaman Bersama keluarga. Apalagi bagi pelaku ekonomi yang memiliki keterkaitan dengan pelaksanaan mudik, seperti pedagang baju, makanan hingga pengusaha Otobus moda transportasi darat, laut dan udara.

Namun belum kering pernyataan Pemerintah, sehari setelahnya juru bicara pemerintah untuk penanganan Covid-19 memberikan pernyataan kebijakan larangan mudik masih digodok. Hal ini didukung pernyataan Ketua Satgas Penanganan Covid-19 yang meminta masyarakat untuk bersabar kebijakan sedang dalam progres. Bahkan pada tanggal 22 Maret 2021, Wapres Ma'aruf Amin memberikan pernyataan terkait pelaksanan mudik belum ada keputusan.

Barulah pada tanggal 26 Maret 2021, Pemerintah mengambil keputusan kebijakan yang bahwa larangan mudik tahun 2021 ditetapkan. Menko Bidang Pembangunan Manusia, Muhadjir Effendi, menyampaikan larangan mudik tahun 2021, dan berlaku untuk seluruh lapisan masyarakat. Keputusan tersebut merupakan arahan Presiden dan hasil rapat koordinasi tingkat menteri.

\section{Indikator keraguan dari Pernyataan yang kontradiktif}

Pengambil kebijakan, pemerintah dalam proses penetapan larangan perjalanan mudik, terdapat berbagai pernyataan yang kontradiktif cenderung ragu ragu, bahkan gamang. Para pejabat-pejabat publik yang hanya berselang beberapa hari memberikan pernyataan yang berubah ubah mengindikasikan adanya keragu-raguan dalam proses kebijakan larangan mudik. Pernyataan diperbolehkannya mudik oleh Menteri Perhubungan tidak dalam regulasi peraturan secara tertulis, hanya karena yang memberikan pernyataan pejabat publik maka akan berdampak signifikan pada publik.

Akhirnya Simpang siur terkait kebijakan larangan mudik final, resmi ditetapkan. Keputusan final yang kontradiktif dengan isu awal yang beredar tersebut berpotensi menimbulkan kekecewaan bagi masyarakat yang menghendaki adanya mudik tahun 2021. 
Terlihat bahwa pengambil kebijakan tidak belajar dari kebijakan larangan mudik di tahun 2020, ketidak konsisten ini menimbulkan dampak negatif. Ketika pemerintah menetapkan kebijakan larangan perjalanan mudik pada 26 maret 2021 sebagai upaya preventif mitigasi resiko penanganan Covid-19 tentu memberikan dampak sosial juga secara ekonomi pada jutaan masyarakat Indonesia. Kebijakan pelarangan mudik 2021 dapat ditarik kesimpulan pada masalah pemilihan waktu, kesesuaian, dan implementasi di lapangan.

\section{Pemilihan waktu, kesesuaian, dan dampaknya}

Mengenai pemilihan waktu, keputusan kebijakan pelarangan mudik terkesan dadakan, kurang dari sebulan sebelum hari raya idul fitri. Masyarakat yang sudah mempersiapkan mudik jauh-jauh hari harus membatalkan rencana termasuk membatalkan keberangkatannya menuju kampung halaman.

Kesesuaian kebijakan larangan mudik ini menjadi masalah. Hal ini dikarenakan, kebijakan larangan mudik pada awalnya hanya himbauan, bukan berupa pelarangan. Terjadi penafsiran bahwa mudik diperbolehkan dengan syarat memperhatikan beberapa hal. Inilah yang jadi pedoman masyarakat dengan berbagai alasan dan pertimbangan tetap memutuskan untuk mudik.

Pada akhirnya kebijakan mudik yang hanya himbauan diubah oleh pemerintah menjadi kebijakan larangan dengan regulasi hanya berupa peraturan menteri. Ketidak konsisten Kebijakan larangan mudik ini menimbulkan persepsi pada masyarakat pemerintah tidak serius. Masalah yang selanjutnya muncul pada saat memasuki waktu mudik. Meskipun sudah dilarang, kenyataannya pada implementasinya di lapangan tidak sedikit masyarakat yang tetap melakukan mudik.

\section{Sebuah Kebijakan Publik merupakan keputusan politik}

Substansi kebijakan publik upaya yang menjadi pilihan pemerintah untuk dilakukan atau tidak dilakukan, merupakan keniscayaan sosial dalam sebuah kebijakan publik. Bagaimana dengan keputusan pemerintah yang tidak sesuai dengan keinginan masyarakat luas. Memahami kebijakan publik sebagai aktivitas menyeluruh pemerintah yang dilakukan secara langsung ataupun melalui perantara yang berdampak pada kehidupan warga Negara (B. Guy Peters dalam bukunya Handbook of Public Policy 2006). Pada bukunya "Public Policy: Perspectives and Choices(1999), Charles L. Cochran dan Eloise F. Malone mendefinisikan bahwa kebijakan publik adalah produk keputusan politik untuk melaksanakan program-program dalam rangka mencapai tujuan-tujuan sosial. 
Seringkali kebijakan publik sebagai produk politik, Terhadap formasi elite politik maupun formasi pendukung (supporter) dalam praktek pembangunan berdampak luas.

Pendekatan kebijakan distributif dan regulatif adalah metode Kebijakan publik. Dalam aplikasi di lapangan, kebijakan distributif berkaitan dengan kebijakan yang mempertimbangkan distribusi sumberdaya pembangunan yang luas baik infrastruktur, modal maupun kebutuhan bersama. Kebijakan distributif merupakan Kebutuhan dasar masyarakat yang diimplementasikan melalui pelayanan publik.

Pada kebijakan regulatif kaitannya dengan kebijakan arah regulasi yang berdampak luas, baik intruksi, edaran, implementasi, perintah maupun larangan. Bila kebijakan distributif dan regulatif ini bisa berjalan seiringan, maka kualitas pelayanan publik akan dihasilkan.

Menjadi kendala pada implementasinya dalam penegakan kebijakan larangan mudik 2021 di lapangan. Sehingga, tujuan dari kebijakan pelarangan mudik untuk meminimalisir persebaran Covid-19 tidak tercapai karena banyaknya masyarakat yang bandel tetap melakukan mudik yang dilakukan sebelum penetapan kalender larangan mudik 2021 dimulai dari tanggal 06 mei hingga 17 mei 2021, dan kepulangannya kembali ke kota pada waktu diatas 17 mei 2021. Satgas Covid 19 antar kota antar propinsi melakukan upaya preventif mitigasi resiko dengan melakukan swab, atau genose di posko posko satgas Covid 19 untuk mengidentifikasi orang orang yang melakukan perjalanan dari kota ke kampung dan sebaliknya dari kampung ke kota kemungkinan terjadi adanya klaster klaster baru.

Dari kebijakan larangan mudik 2021 dengan regulasi seperti permenhub, sesuai dengan regulasi UU No.6 Tahun 2018 Karantina Kesehatan Pemerintahan Lampung Bersama satgas Covid 19 berkolaborasi melakukan upaya preventif melalui anggaran Covid 19 melakukan Swab Antigen kepada para pengguna jasa moda transportasi darat sebelum menyeberang melalui Pelabuhan Bakauheni Lampung.

Pengendalian Covid-19 dilakukan Pemerintahan lampung dengan melakukan Swab Antigen kepada para pengguna jasa moda transportasi darat yang akan menyeberang melalui Pelabuhan Bakauheni Lampung salah satu opsi upaya preventif dan standar Prosedur Kesehatan (Prokes), yang dipilih oleh pemerintahan Lampung didasarkan pada Undang-Undang Nomor 6 Tahun 2018 tentang Kekarantinaan Kesehatan. Swab antigen upaya preventif dan standa prosedur kesehatanmengetahui , tracking para pengguna jasa 
moda transportasi darat untuk mencegah kemungkinan penyebaran penyakit atau kontaminasi.

Pada implementasi larangan mudik 2021, Pemerintahan Lampung Bersama satgas Covid 19 terkait dengan pembatasan orang orang yang mudik 2021 melakukan pelayan publik dengan pembatasan mudik standar protokol Kesehatan dengan $3 \mathrm{~m}$, mencuci tangan, memakai masker, menjaga jarak maupun kerumunan orang banyak, lalu melakukan tes swab atau genose dengan pihak terkait untuk mendokumentasikan kesehatannya. Tujuannya agar tidak melahirkan klaster klaster baru dalam pembatasan orang orang yang melakukan mudik.

\section{KESIMPULAN}

Tata kelola pelayanan publik pemenuhan logika, etika, hukum, estetika, dan kebijakan lain lain, tugas Pemerintahan lampung sebagai pelayan publik ditengah kebijakan larangan mudik yang dilakukan oleh Pemerintah Pusat melakukan inivasi dan inisiasi di lapangan berdasarkan pemahaman falsafah dan prinsip pelayanan publik yang prima, untuk menjemput pelayanan yang dengan ukuran Paradigma Lovelock pelayanan Publik yaitu:

Reliability dengan sikap dan perilaku Satgas Covid 19 terkait dalam melayani para pengguna jasa moda transportasi darat dengan upaya preventif mentracking para pengguna jasa moda transpotasi darat melalui swab antigen.

Responsiveness, merespon dengan baik, dengan kesigapan satgas Covid bersama Nakes dalam melakukan swab antigen, hingga memisahkan bila ada para pengguna jasa moda transportasi darat yang positif Covid 19

Assurance: Pemerintahan Lampung bersama satgas Covid 19 dan nakes tenaga kesehatan memenuhi ekspektasi jaminan pada para pengguna jasa moda transportasi darat dengan upaya preventif swab antigen standar prosesur kesehatan.

Empathy (perhatian pribadi), kepedulian Satgas Covid 19 bersama nakes dalam melakukan pelayanan yang humanis.

Tangible: Penampilan satgas Covid 19 bersama nakes santun dan rapi, hingga diperlukan peningkatan fasilitas menunggu ketika antri swab antigen agar pengguna jasa moda transportasi darat, dalam ketersediaan tempat duduk ketika menunggu, serta jaminan keamanan pada ramainya kerumunan orang orang. 
Faktor eksternal diluar 5 (lima) aspek tersebut turut mempengaruhi kualitas pelayanan pada implementasi kebijakan Larangan Mudik 2021 seperti kerumunan penyebab antrian Swab Antigen, hal tersebut menjadi penyebaba tidak terjaga prosedur kesehatan.

\section{REFERENSI}

Putri Yulfa Rianti dan Retnowati WD Tuti. 2017. Kualitas Pelayanan Transjakarta busway di DKI jakarta

Nopriadi Saputra. 2021. Manajemen dan kepemimpinan kontemporer: A Scholarly Practitioner Perspective

Evi Satispi, Kurniasih Mufidayati. 2019. The implementation of the Jakarta smart city (JSC)

Maryam, Siti, Soesilo Zauhar, Choirul Saleh. 2016. Strategi Perencanaan Peningkatan Kualitas Pelayanan Publik (Studi Pada Pelayanan Administrasi Kependudukan di Kabupaten Sampang). Universitas Brawijaya Malang. Wacana- Vol.19, No. 2

Taufqurokhman, A.ks., S.Sos., M.Si, Dr, Dr. Evi Satispi, SP.M.Si. 2018.Teori dan Perkembangan Manajemen Pelayanan Publik. Tangerang Selatan. UMJ Press

Dini Rizki Fitriani.2017. Mewujudkan Good Governancemelalui Pelayanan Publik dalam Era Otonomi Daerah

Allen (2016). Conceptualizing learning agility and investigating its nomological network. Florida International University

Abel, G. J., \& Sander, N. (2014). Quantifying Global International Migration Flows. Science, 343(6178), 1520-1522. https://doi.org/10.1126/science.1248676

Gu, Z., Gu, L., Eils, R., Schlesner, M., \& Brors, B. (2014). Circlize implements and enhances circular visualization in R. Bioinformatics, 30(19), 2811-2812. https://doi.org/10.1093/bioinformatics/btu393

Gugus Tugas Percepatan Penanganan COVID-19. (2020). Peta Sebaran. Retrieved 4 Juni 2020 from https://covid19.go.id/peta-sebaran

Hisi, A. N. S., Macau, E. E. N., \& Tizei, L. H. G. (2019). The role of mobility in epidemic dynamics. Physica A: Statistical Mechanics and its Applications, 526, 1-8. https://doi.org/10.1016/j.physa.2019.03.028

Iriyanto, A. M. (2012). Mudik dan Keretakan Budaya. Humanika, 15(9). https://doi.org/10.14710/humanika.15.9.

Ivakhnyuk, I. (2020). Coronavirus pandemic challenges migrants worldwide and in Russia. Population and Economics, 4(2), 49-55. https://doi.org/10.3897/popecon.4.e53201

Lestari, F. (2019). Kajian Karakteristik Arus Mudik Lebaran Menggunakan Survei Online. Jurnal Penelitian Transportasi Darat, 21(1), 31-36. https://doi.org/10.25104/jptd.v21i1.1165

Zeinthaml, V.A. Parasuraman \& L.L. Berry. 1990. Delivering Quality Service, Balancing Customer Perseptions and Expectation, New York: The Free Pres 
Merler, S., \& Ajelli, M. (2012). Human mobility and population heterogeneity in the spread of an epidemic. Procedia Computer Science, 1(1), 2237-2244. https://doi.org/10.1016/j.procs.2010.04.250

Qi, W., Abel, G. J., Muttarak, R., \& Liu, S. (2017). Circular visualization of China's internal migration flows 2010-2015. Environment and Planning, 49(11), 2432-2436. https://doi.org/10.1177/0308518X17718375

Somantri, G. R. (2007). Kajian Sosiologis Fenomena Mudik. Universitas Indonesia. http://staff.ui.ac.id/system/files/users/gumilar.r $\quad 09 /$ publication/kompilasibuku.pdf

Gaspersz Vincent. Service,Quality, dan Satifaction,dalam Lukman Sampara. Manajemen Kualitas Pelayanan.(Jakarta:STIA LAN press,2004). P .10

Gaspersz Vincent. Manajemen Kualitas dalam industri jasa.dalam Lukman Sampara.Mana- jemen Kualitas Pelayanan.(Jakarta :STIA LAN press,2004). P.9

Lehtinen (1983), dalam Lukman, Sampara.Mana- jemen Kualitas Pelayanan. (Jakarta :STIA LAN Press,2004). P .8

Lukman, Sampara. Manajemen Kualitas Pelayan- an (Jakarta :STIA LAN Press,2004) Lovelock (1981), dalam Faozan,Haris. Peran Bi- rokrasi Manajemen Kebijakan dan Eksistensi Pelayanan Publik.(Jakarta:Pusat Kajian Kinerja Kelembagaan, LAN,2003). P. 120-121

Moenir H.A.S.Manajemen Pelayanan umum Di In- donesia. (Jakarta :Bumiaksara ,2002). p.16-17

Moenir H.A.S.Manajemen Pelayayan Umum Di In- donesia.(Jakarta :Bumi Aksara, 2006). p.17

Nogi S, Hessel, Tangkilisan. Manajemen Publik.( PT Grasindo, 2005). p.209

Patricia Patton. EQ- Pelayanan Sepenuh Hati .da- lam Lukman,Sampara.Manajemen Kualitas Pe- layanan (jakarta : STIA LAN Press, 2004)

Pasolong, Harbani.Teori Administrasi Publik. ( Al- fabeta, 2014). p.132

Sugiyono. (2012). Metode Penelitian Kuantitatif, Kualitatif dan R \& D.Bandung:Alfabeta. Metode Penelitian Kuantitatif, Kualitatif Dan R \& D.Bandung:Alfabeta. https://doi.org/10.1017/CB09781107415324.004 